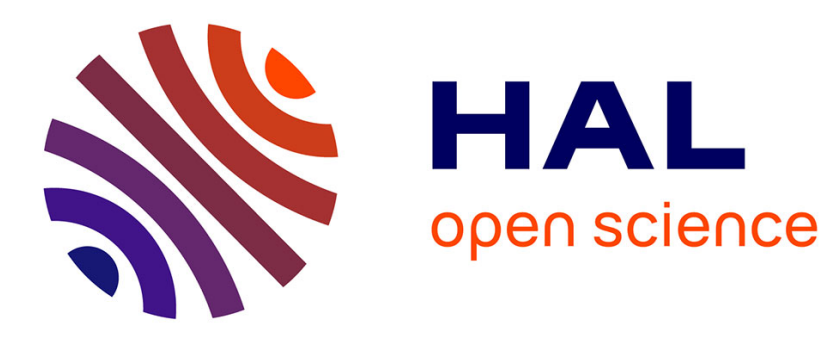

\title{
Improvement in patient-reported outcomes after rituximab in rheumatoid arthritis patients: An open-label assessment of 175 patients
}

Laure Gossec, Agnès Danré, Bernard Combe, Xavier Le Loët, Jaques Tebib, Jean Sibilia, Xavier Mariette, Maxime Dougados

\section{To cite this version:}

Laure Gossec, Agnès Danré, Bernard Combe, Xavier Le Loët, Jaques Tebib, et al.. Improvement in patient-reported outcomes after rituximab in rheumatoid arthritis patients: An open-label assessment of 175 patients. Joint Bone Spine, 2015, 82 (6), pp.451-454. 10.1016/j.jbspin.2015.02.007 . hal01189082

\section{HAL Id: hal-01189082 https://hal.sorbonne-universite.fr/hal-01189082}

Submitted on 1 Sep 2015

HAL is a multi-disciplinary open access archive for the deposit and dissemination of scientific research documents, whether they are published or not. The documents may come from teaching and research institutions in France or abroad, or from public or private research centers.
L'archive ouverte pluridisciplinaire HAL, est destinée au dépôt et à la diffusion de documents scientifiques de niveau recherche, publiés ou non, émanant des établissements d'enseignement et de recherche français ou étrangers, des laboratoires publics ou privés. 


\section{Concise report}

Improvement in patient-reported outcomes after rituximab in rheumatoid arthritis patients: an open-label assessment of 175 patients.

Laure Gossec ${ }^{1}$, Agnès Danré ${ }^{1}$, Bernard Combe ${ }^{2}$, Xavier Le Loët ${ }^{3}$, Jaques Tebib ${ }^{4}$, Jean Sibilia $^{5}$, Xavier Mariette ${ }^{6}$, Maxime Dougados $^{7}$

Name of department(s) and institution(s) to which the work should be attributed.

${ }^{1}$ Sorbonne Universités, UPMC Univ Paris 06, Institut Pierre Louis d'Epidémiologie et de Santé Publique; AP-HP, Pitié Salpêtrière Hospital, Department of rheumatology, F-75013, Paris, France

${ }^{2}$ Lapeyronie University Hospital, Montpellier I University; UMR5535, Montpellier, France

${ }^{3}$ Rouen University Hospital and INSERM U905, Rouen, France

${ }^{4}$ Centre hospitalier Lyon Sud, Pierre-Benite, France

${ }^{5}$ Hopitaux Universitaires de Strasbourg and Université de Strasbourg, Strasbourg, France

${ }^{6}$ Hôpital Bicêtre, APHP, INSERM U1012, and Université Paris-Sud 11, Le Kremlin Bicêtre, France

${ }^{7}$ Paris-Descartes University; APHP, Cochin Hospital, Rheumatology B Department, Paris, France

\section{Authors and degrees}

L Gossec, MD, PhD; A Danré, MD; B Combe, MD, PhD; X Le Loët, MD, PhD; J Tebib, MD, $\mathrm{PhD}$; J Sibilia, MD, PhD; X Mariette, MD, PhD; M Dougados, MD.

\section{Corresponding author (and address for reprint requests)}

Pr. Laure Gossec, Service de rhumatologie, hôpital Pitié-Salpetrière, 47-83, Bd de l'Hôpital, 75013 Paris France laure.gossec@psl.aphp.fr

tel. $+33-142178421$ 


\section{Abstract}

Objective: Patient-reported outcomes (PROs) reflect treatment efficacy from the patients' perspective. The objective was to assess PROs improvement with rituximab in rheumatoid arthritis.

Methods: Patients with long-standing rheumatoid arthritis received rituximab $1000 \mathrm{mg}$ twice at 2 weeks interval, and were assessed over 6 months. PROs including physical PROs (pain, functional assessment, physical quality of life) and mental or mixed aspects (fatigue, sleep and mental quality of life) were assessed. Standardized response means were calculated. Early improvement in PROs was used to predict EULAR response at 6 months.

\section{Results:}

For the 175 patients (mean age $54.6 \pm 10.6$ years, mean disease duration $12.9 \pm 9.3$ years), the plateau of efficacy of rituximab on PROs was reached at week 12, and the effect was more prominent on physical PROs (e.g., pain standardized response means -0.75 [95\% confidence interval $-0.91 ;-0.60])$, than on sleep $(-0.43 ;[-0.56 ;-0.29])$. It was not possible to accurately predict 6-month EULAR response by early improvement in PROs.

Conclusion: Rituximab was effective on PROs with an early effect. PROs reflecting physical aspects were more modulated by this biologic than other PROs (fatigue, sleep or mental quality of life). Links between sleep difficulties, fatigue and RA should be further studied.

\section{Keywords}

Rheumatoid arthritis, pain, sleep, quality of life, rituximab.

Word count: 1593 words (limit 2400 words, 30 references, 4 tables/figures) 


\section{Introduction}

Patient-reported outcomes (PROs) reflect the patient's perspective and are increasingly recognised as an important parameter in rheumatoid arthritis (RA) including when assessing treatment efficacy (1-5). PROs can be divided in outcomes related to physical aspects such as function or pain, and outcomes related to mental functioning e.g. depression but also probably fatigue or sleep.

Trials of rituximab (RTX) have demonstrated its efficacy on RA disease activity, and on some essential PROs such as pain, functional impairment, fatigue and patient global assessment (PGA) (6-9). However, few data are available concerning the magnitude of effect of RTX on PROs or its impact on some aspects of the disease such as mental outcomes or sleep. Furthermore, because courses of RTX are usually administered at 6 month-intervals, patients may be anxious to know when (during this interval) they could experience improvement of their symptoms. Thus, it could be interesting to know the delay before onset of efficacy on PROs, as well as factors related to an early effect.

Physicians would like to be able to predict response to therapy as early as possible. Our hypothesis is that patient's assessment of efficacy, early on after a treatment change, could predict later efficacy on composite measures such as the disease activity score (DAS). If this is the case, it might allow earlier treatment changes, according to patients' assessment.

The objectives of the present study were to explore the effects of RTX on PROs, and in particular (a) to compare the improvement in PROs after RTX (b) to assess the delay before PROs improvement after the infusions and its predictive factors and (c) to assess if early patient-reported improvement was predictive of response, at week 24.

\section{Patients and Methods}

\section{Study design}

SMART (eSsai MAbthera sur la dose de Re-Traitement) was a 2-year, national, multicenter, randomized, open-label study evaluating 2 strategies of re-treatment in patients responding to RTX after 1 course (1,000 mg on days 1 and 15)(11). In this ancillary study, only data from the first phase of the SMART trial were used: patients were treated with RTX (1000 mg twice, with a premedication of $100 \mathrm{mg}$ of IV methylprednisolone each time) and followed-up (open-label phase), here only the first 6 months were analysed. 


\section{Patients}

Patients included had RA (according to American College of Rheumatology 1987 revised classification criteria (12)), and had active disease, defined by a Disease Activity Score in 28 joints (DAS28) using the C-reactive protein (DAS28-CRP) of $>3.2$ associated with $\geq 6$ of 66 swollen joints and $\geq 6$ of 68 tender joints, or a CRP level of $\geq 10 \mathrm{mg} /$ liter (normal $\leq 5 \mathrm{mg} / \mathrm{liter}$ ), or an erythrocyte sedimentation rate of $\geq 28 \mathrm{~mm} /$ hour. Each patient received a stable dose of methotrexate ( $\geq 10 \mathrm{mg} /$ week for at least 4 weeks) and had experienced an inadequate response or intolerance to Tumor Necrosis Factor inhibitors. The population of interest included only patients with SF12 data at 6 months.

\section{Assessment of PROs and timeframe for improvement}

PROs assessed at baseline, week 6, 12 and 24 were pain and patient global assessment (PGA) by visual analogue scale (VAS), functional assessment by the Health Assessment Questionnaire, HAQ (13), fatigue (by VAS), and quality of sleep by the Medical Outcomes Study - MOS Sleep questionnaire (14). Quality of life (QoL) both mental and physical, was assessed by the Short-form 12 (SF12) at baseline and 24 weeks (15).

\section{Response to RTX at week 24}

Response at week 24 was defined according to changes in DAS levels by a EULAR good to moderate response (16).

\section{Statistical analyses}

Missing data were imputed using the last observation carried forward technique.

To compare improvement in the different PROs after RTX treatment, standardised response means (SRMs) (change/ standard deviation, SD, of change) were calculated (17). Confidence intervals $(95 \% \mathrm{Cl})$ were estimated by bootstrapping. A SRM is usually considered large if $>0.8$. To determine baseline predictive factors of early PGA improvement, PGA improvement of $30 \%$ at week 12 was explained by univariate logistic regression. Baseline explanatory variables included gender, age, disease duration, presence of radiological erosions, positivity of rheumatoid factor or anti cyclic citrullinated protein (CCP), DAS28 CRP, anaemia (haemoglobin $<11 \mathrm{~g} / \mathrm{dl}$ ), oral glucocorticoid intake, HAQ and pain VAS. To assess if early response for PROs was associated with DAS response to RTX, both univariate logistic regression to explain EULAR good to moderate response (by DAS 28 at week 24) and a $2 \times 2$ table were calculated. 


\section{Results}

\section{Patient characteristics}

Of the 224 patients, 175 had SF12 data available at 6 months (Table 1): mean age was 54.6 ( \pm standard deviation 10.6$)$ years, disease duration $12.9( \pm 9.3)$ years, and $146(83.4 \%)$ were women. Patients reported high disease activity at baseline: mean DAS28-CRP $5.8( \pm 0.9)$. Rituximab was efficacious on disease activity: mean DAS28-CRP at 6 months was 4.2 $( \pm 1.2)$.

Patients had high symptom levels and in particular high pain and fatigue: mean baseline pain and fatigue VAS were respectively $60.7( \pm 21.6) \mathrm{mm}$ and $62.6( \pm 22.3) \mathrm{mm}$.

\section{Effect of rituximab on different PROs}

PROs were improved after RTX (Table 2) but the effect at week 12 was much clearer on $P G A$, pain and $H A Q$ than on sleep.

A plateau for PROs was reached at week 12 with stability of results between 12 and 24 weeks (figure 1).

Neither demographic data, nor disease characteristics at baseline could predict an early improvement in PGA (data not shown).

\section{Prediction of DAS response by early PRO response}

PROs improvement seemed to be predictive for a moderate or good EULAR response at week 24, except fatigue at week 6 (supplementary online Table 1).

However, the link between improvement in PROs at weeks 6 and 12 and the DAS28 response at week 24 was low. Specifically, among patients presenting a DAS28 moderate or good response at week 24, 69 patients (66.3\%\%) had no improvement in PGA at week 6, and $45(56.3 \% \%)$ had no improvement in PGA at week 12. Reversely however, only 10 patients at week 6 and 11 patients at week 12 with improved PGA had no DAS28 response at week 24.

\section{Discussion}

Assessment of PROs represents an important issue in studying efficacy of treatments in RA. In the present study, similarly to previous studies, RTX treatment led to improvement as measured by PROs $(8,9)$. Nevertheless, this study indicated that PROs reflecting physical aspects (pain, functional disability, PGA, physical quality of life) were more modulated by this biologic than other PROs (fatigue, sleep or mental quality of life). Specifically, this study is 
the first to report the effects of RTX on sleep difficulties; small effect sizes indicate the link between sleep difficulties and the physiopathology of RA should be further studied. An interesting aspect is early prediction of response, through the patient's assessment. In the present study, it was not possible to predict early on, either PRO response, nor DAS response using PROs.

Our analysis has some limitations. Firstly, PROs are self-reported assessments and interpretation might be biased by treatment expectations, particularly at the early phases after treatment administration in such an open-label study. However, such expectations would modify all the outcomes, not only some of the PROs assessed here. Secondly, RA is a chronic disease, but PROs were studied here only over 24 weeks: it is possible impact on improvement in mental components could be observed later, after a sufficient delay, or after retreatments with $\mathrm{RTX}$.

The use of standardized response means allows the comparison of effects across different PROs; 0.80 represents a large response (18). Maximal effect on PROs was reached by week 12 indicating that most patients will experience an improvement in their status by that time point. In the REFLEX study, Keystone et al found an improvement in PROs early on (at week 4) in both the placebo and RTX groups, probably due to background steroids, and a significantly greater improvement was found only in the RTX group at week 8 (19). The present data brings more information on rapidity and sustainability of this efficacy on PROs. However, it was not possible to predict early improvement in PGA after 2 RTX infusions in the present study, which confirms the difficulties to predict response in RA patients (20).

The effects of biologics on PROs is more and more studied, because it allows physicians to appreciate the effect of drugs according to the patient's opinion. Other biologics have also demonstrated effects on PROs, which appear to be of a similar magnitude (21).

Fatigue was improved after RTX in the present study, confirming previous results (9). However, 'mental' PROs including fatigue had less magnitude in response to RTX which brings new insights into the links between fatigue or quality of sleep and RA disease activity.

Changes in PROs at week 6 and week 12 were associated with EULAR response to RTX at week 24 , except fatigue at week 6 . Thus, patients with no relevant improvement of fatigue at week 6 may still be responders at week 24: fatigue should not be a decision-making criterion in the early post-RTX therapy phase.

Furthermore, the link between improvement in PGA and later improvement in DAS was low: a substantial number of patients who did not show relevant improvement in PGA at 6 or 12 
weeks after the infusions still responded later to RTX in terms of DAS. Therefore it may be useful to continue with this treatment even when patients do not feel initial improvement.

In conclusion, we demonstrated here the positive impact of RTX on physical PROs after the first course. "Mental" PROs (MOS sleep, mental quality of life) were not as significantly improved. These conclusions should be interpreted at an individual level, particularly in cases of multiple therapy failures. 
Table 1.Baseline characteristics of 175 RA patients receiving a course of rituximab and followed up over 6 months

\begin{tabular}{|c|c|}
\hline & Total \\
\hline Females, n (\%) & $146(83.4 \%)$ \\
\hline Age, years & $54.6 \pm 10.6$ \\
\hline RA duration, years & $12.9 \pm 9.3$ \\
\hline Presence of rheumatoid factor $n(\%)$ & $114(65.5 \%)$ \\
\hline Presence of anti-citrullinated protein antibodies $\mathrm{n}(\%)$ & $133(76.4 \%)$ \\
\hline DAS28-CRP & $5.8 \pm 0.9$ \\
\hline Pain VAS, mm & $60.7 \pm 21.6$ \\
\hline Fatigue VAS, mm & $62.6 \pm 22.3$ \\
\hline HAQ score & $1.8 \pm 0.6$ \\
\hline Patient global VAS, mm & $64.0 \pm 19.8$ \\
\hline MOS-Sleep & $51.8 \pm 15.7$ \\
\hline SF12-physical & $30.9 \pm 7.1$ \\
\hline SF12-mental & $36.2 \pm 9.3$ \\
\hline Current prednisone use, $\mathrm{n}(\%)$ & $136(77.7 \%)$ \\
\hline Methotrexate dosage, mg/week & $14.1( \pm 3.6)$ \\
\hline Prednisone dosage for patients using it, $\mathrm{mg} / \mathrm{d}$ & $8.2( \pm 2.7)$ \\
\hline
\end{tabular}

Except where indicated otherwise, values are the mean \pm SD. DAS28-CRP $=$ Disease Activity Score for 28 joints using the C-reactive protein level; $\mathrm{HAQ}=$ Health Assessment Questionnaire disability index; MOS-Sleep = Medical Outcomes Study Sleep questionnaire; SF-12: Short-Form 12 questionnaire, mental and physical components. 
Table 2._Efficacy of rituximab on different PROs in 175 RA patients, ordered by decreasing response

\begin{tabular}{|c|c|c|c|}
\hline \multirow[t]{2}{*}{ Outcome } & \multicolumn{3}{|c|}{$\begin{array}{c}\text { Improvement from baseline } \\
\text { standardized response means [95\%Cl] }\end{array}$} \\
\hline & Week 6 & Week 12 & Week 24 \\
\hline DAS-28 CRP & $\begin{array}{c}-1.11 \\
{[-1.3 ;-0.93]}\end{array}$ & $\begin{array}{c}-1.38 \\
{[-1.57 ;-1.19]}\end{array}$ & $\begin{array}{c}-1.3 \\
{[-1.48 ;-1.11]}\end{array}$ \\
\hline Patient global (mm) & $\begin{array}{c}-0.62 \\
{[-0.77 ;-0.47]}\end{array}$ & $\begin{array}{c}-0.83 \\
{[-0.98 ;-0.68]}\end{array}$ & $\begin{array}{c}-0.83 \\
{[-0.98 ;-0.68]}\end{array}$ \\
\hline SF12-physical & NA & NA & $\begin{array}{c}0.79 \\
{[0.64 ; 0.93]}\end{array}$ \\
\hline Pain (mm) & $\begin{array}{c}-0.53 \\
{[-0.68 ;-0.37]}\end{array}$ & {$\left[\begin{array}{c}-0.75 \\
{[-0.91 ;-0.59]}\end{array}\right.$} & $\begin{array}{c}-0.75 \\
{[-0.91 ;-0.6]}\end{array}$ \\
\hline Function (HAQ) & $\begin{array}{c}-0.47 \\
{[-0.61 ;-0.32]}\end{array}$ & $\begin{array}{c}-0.68 \\
{[-0.82 ;-0.54]}\end{array}$ & $\begin{array}{c}-0.62 \\
{[-0.75 ;-0.5]}\end{array}$ \\
\hline Fatigue $(\mathrm{mm})$ & {$\left[\begin{array}{c}-0.32 \\
{[-0.47 ;-0.17]}\end{array}\right.$} & $\begin{array}{c}-0.55 \\
{[-0.7 ;-0.41]}\end{array}$ & $\begin{array}{c}-0.61 \\
{[-0.76 ;-0.46]}\end{array}$ \\
\hline Sleep (MOS) & $\begin{array}{c}-0.34 \\
{[-0.48 ;-0.2]}\end{array}$ & $\begin{array}{c}-0.44 \\
{[-0.59 ;-0.3]}\end{array}$ & $\begin{array}{c}-0.43 \\
{[-0.56 ;-0.29]}\end{array}$ \\
\hline SF12-mental & NA & NA & $\begin{array}{c}0.38 \\
{[0.23 ; 0.53]}\end{array}$ \\
\hline
\end{tabular}

NA : not available. 
Figure 1. Variation of different PROs in the 6 months following RTX.

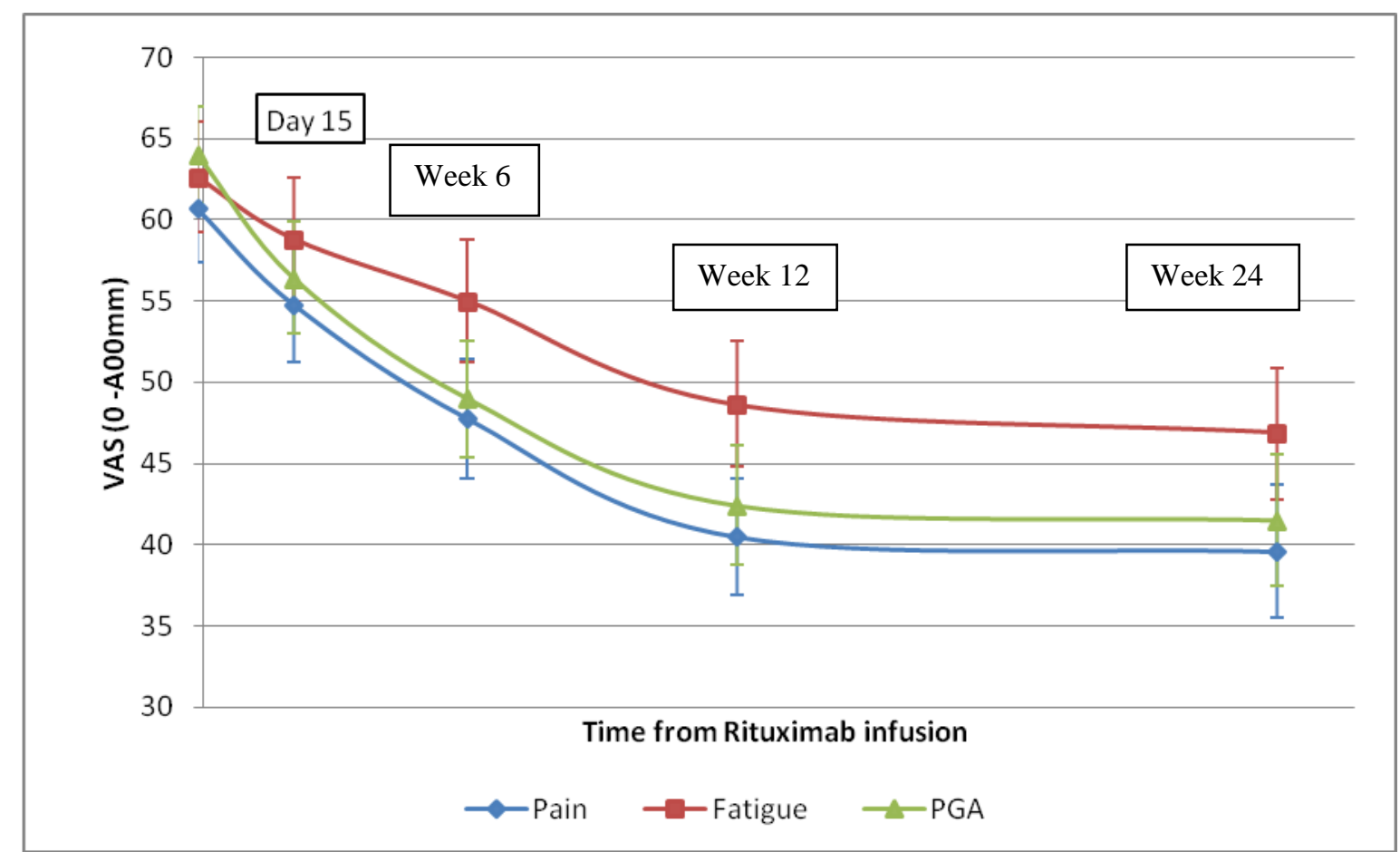


Online supplementary Table 1: Improvement in PROs at week 6 and week 12 and EULAR response at week 24 in univariate analysis

Univariate analysis results

\begin{tabular}{|c|c|c|c|}
\hline & $\begin{array}{c}\text { No EULAR } \\
\text { response at } \\
\text { week } 24 \\
\mathrm{~N}=49 \\
\mathrm{~N}(\%)\end{array}$ & $\begin{array}{c}\text { Moderate or good } \\
\text { EULAR response at } \\
\text { week } 24 \\
\begin{array}{c}\mathrm{N}=125 \\
\mathrm{~N}(\%)\end{array}\end{array}$ & $\begin{array}{l}\text { Odds ratio and } \mathrm{P} \\
\text { value (univariate } \\
\text { analysis) }\end{array}$ \\
\hline $\begin{array}{l}\text { Improvement in } \mathrm{HAQ} \text { at } \\
\text { week } 6 \text {, yes versus no }\end{array}$ & $\begin{array}{l}17(21.5 \%) \\
31(35.2 \%)\end{array}$ & $\begin{array}{l}62(78.5 \%) \\
57(64.8 \%)\end{array}$ & $\begin{array}{c}1.98[0.99,3.96] \\
0.053\end{array}$ \\
\hline $\begin{array}{l}\text { Improvement in VAS pain } \\
\text { at week } 6 \text {, yes versus no }\end{array}$ & $\begin{array}{l}9(15 \%) \\
36(33 \%)\end{array}$ & $\begin{array}{l}51(85 \%) \\
73(67 \%)\end{array}$ & $\begin{array}{c}2.79[1.24,6.30] \\
0.01\end{array}$ \\
\hline $\begin{array}{c}\text { Improvement in VAS } \\
\text { fatigue at week } 6 \text {, yes } \\
\text { versus no }\end{array}$ & $\begin{array}{l}10(21.7 \%) \\
35(28.7 \%)\end{array}$ & $\begin{array}{l}36(78.3 \%) \\
87(71.3 \%)\end{array}$ & $\begin{array}{c}1.45[0.65,3.23] \\
0.37\end{array}$ \\
\hline $\begin{array}{l}\text { Improvement in VAS PGA } \\
\text { at week } 6 \text {, yes versus no }\end{array}$ & $\begin{array}{l}10(15.4 \%) \\
35(33.7 \%)\end{array}$ & $\begin{array}{l}55(84.6 \%) \\
69(66.3 \%)\end{array}$ & $\begin{array}{c}2.79[1.27,6.13] \\
0.01\end{array}$ \\
\hline $\begin{array}{l}\text { Reducing DAS } 28 \text { CRP at } \\
\text { week } 6 \text {, yes versus no }\end{array}$ & $\begin{array}{l}15(13.6 \%) \\
30(54.5 \%)\end{array}$ & $\begin{array}{l}95(86.4 \%) \\
25(45.5 \%)\end{array}$ & $\begin{array}{c}7.60[3.55,16.26] \\
<0.0001\end{array}$ \\
\hline $\begin{array}{l}\text { Improvement in } \mathrm{HAQ} \text { at } \\
\text { week } 12 \text {, yes versus no }\end{array}$ & $\begin{array}{l}18(18.8 \%) \\
31(41.3 \%)\end{array}$ & $\begin{array}{l}78(81.3 \%) \\
44(58.7 \%)\end{array}$ & $\begin{array}{c}3.05[1.53,6.08] \\
0.002\end{array}$ \\
\hline $\begin{array}{l}\text { Improvement in VAS pain } \\
\text { at week } 12, \text { yes versus no }\end{array}$ & $\begin{array}{l}12(12.9 \%) \\
34(43.6 \%)\end{array}$ & $\begin{array}{l}81(87.1 \%) \\
44(56.4 \%)\end{array}$ & $\begin{array}{c}5.22[2.46,11.08] \\
<0.0001\end{array}$ \\
\hline $\begin{array}{c}\text { Improvement in VAS } \\
\text { fatigue at week 12, yes } \\
\text { versus no }\end{array}$ & $\begin{array}{l}11(16.9 \%) \\
35(33.3 \%)\end{array}$ & $\begin{array}{l}54(83.1 \%) \\
70(66.7 \%)\end{array}$ & $\begin{array}{c}2.46[1.14,5.27] \\
0.02\end{array}$ \\
\hline $\begin{array}{l}\text { Improvement in VAS PGA } \\
\text { at week } 12 \text {, yes versus no }\end{array}$ & $\begin{array}{l}11(12.1 \%) \\
35(43.8 \%)\end{array}$ & $\begin{array}{l}80(87.9 \%) \\
45(56.3 \%)\end{array}$ & $\begin{array}{c}5.66[2.62,12.21] \\
<0.0001\end{array}$ \\
\hline $\begin{array}{l}\text { Reducing DAS } 28 \text { CRP at } \\
\text { week } 12 \text {, yes versus no }\end{array}$ & $\begin{array}{l}22(16.4 \%) \\
25(71.4 \%)\end{array}$ & $\begin{array}{l}112(83.6 \%) \\
10(28.6 \%)\end{array}$ & $\begin{array}{c}12.73[5.36,30.20] \\
<0.0001\end{array}$ \\
\hline
\end{tabular}

PGA : patient global assessment. VAS: visual analog scale.

HAQ improvement was defined as a decrease of at least 0.22 points; VAS improvements were defined as a decrease of at least $30 \%$. 
Percentages are in line not columns 


\section{Acknowledgments}

The authors would like to thank the SMART investigators (all in France): Dr I Azais (Poitiers), Dr JC Balblanc (Belfort), Dr F Berenbaum (Paris), Dr P Bertin (Limoges), Dr M-C Boissier (Bobigny), Dr P Bourgeois (Paris), Dr A Cantagrel (Toulouse), Dr P Carli (Toulon), Dr P-Y Chouc (Marseille), Dr M Couret (Valence), Dr L Euller-Ziegler (Nice), Dr P Fardellone (Amiens), Dr P Fauquert (Berck/Mer), Dr R-M Flipo (Lille), Dr P Gaudin (Echirolles), Dr J-L Grauer (Aix en Provences), Dr A Heraud (Libourne), Dr P Hilliquin (Corbeil), Dr S Hoang (Vannes), Dr E Houvenagel (Lomme), Dr D Keita (Paris), Dr S Lassoued (Cahors), Dr L Le Dantec (Lievin), Dr J-M Le Parc (Boulogne), Dr L Lequen (Pau), Dr F Lioté, (Paris), Dr C Marcelli (Caen), Dr O Meyer (Paris), Dr J-L Pellegrin (Pessac), Dr A Perdriger (Rennes), Dr G Rajzbaum (Paris), Dr S Redeker (Abbeville), Dr J-M Ristori (Clermont-Ferrand), Dr A Saraux (Brest), Dr G Tanguy (La Roche sur Yon), Dr T Thomas (Saint-Priest-en-Jarez), Dr L Zabraniecki (Toulouse), Dr C Zarnitski (Montivilliers).

\section{Conflicts of interest}

Roche France sponsored and designed the SMART study but did not participate in the design, data collection, or interpretation of the results of this ancillary study, which was proposed by an independent scientific committee.

This study was supported by Roche France.

$\mathrm{BC}, \mathrm{XLL}, \mathrm{JT}, \mathrm{JS}, \mathrm{XM}$ and $\mathrm{MD}$ have received honoraria from Roche as members of the scientific committee for this study.

LG has received speakers' fees or honoraria from AbbVie, Celgene, Chugai, Janssen, Novartis, Pfizer, Roche, and UCB. 


\section{References}

1. Kalyoncu U, Dougados M, Daurès JP, Gossec L. Reporting of patient-reported outcomes in recent trials in rheumatoid arthritis: a systematic literature review. Ann Rheum Dis. 2009;68(2):183-90.

2. Gossec L, Dougados M, Rincheval N, Balanescu A, Boumpas DT, Canadelo S, et al. Elaboration of the preliminary Rheumatoid Arthritis Impact of Disease (RAID) score: a EULAR initiative. Ann Rheum Dis. 2009;68(11):1680-5.

3. Dougados $M$, Nataf $H$, Steinberg G, Rouanet $S$, Falissard B. Relative importance of doctor-reported outcomes vs patient-reported outcomes in DMARD intensification for rheumatoid arthritis: the DUO study. Rheumatology (Oxford). 2013;52(2):391-9.

4. Curtis JR, Shan Y, Harrold L, Zhang J, Greenberg JD, Reed GW. Patient perspectives on achieving treat-to-target goals: a critical examination of patientreported outcomes. Arthritis Care Res (Hoboken). 2013;65(10):1707-12.

5. Khan NA, Spencer HJ, Abda EA, Alten R, Pohl C, et al; QUEST-RA group. Patient's global assessment of disease activity and patient's assessment of general health for rheumatoid arthritis activity assessment: are they equivalent? Ann Rheum Dis. 2012;71(12):1942-9.

6. Edwards JCW, Szczepanski L, Szechinski J, Filipowicz-Sosnowska A, Emery P, Close DR, et al. Efficacy of B-cell-targeted therapy with rituximab in patients with rheumatoid arthritis. N Engl J Med. 2004;350(25):2572-81.

7. Keystone EC, Cohen SB, Emery P, Kremer JM, Dougados M, Loveless JE, et al. Multiple courses of rituximab produce sustained clinical and radiographic efficacy and safety in patients with rheumatoid arthritis and an inadequate response to 1 or more tumor necrosis factor inhibitors: 5-year data from the REFLEX study. J Rheumatol. 2012;39(12):2238-46

8. Mease PJ, Revicki DA, Szechinski J, Greenwald M, Kivitz A, Barile-Fabris L, et al. Improved health-related quality of life for patients with active rheumatoid arthritis receiving rituximab: Results of the Dose-Ranging Assessment: International Clinical Evaluation of Rituximab in Rheumatoid Arthritis (DANCER) Trial. J Rheumatol. 2008;35(1):20-30.

9. Rigby W, Ferraccioli G, Greenwald M, Zazueta-Montiel B, Fleischmann R, Wassenberg $S$, et al. Effect of rituximab on physical function and quality of life in patients with rheumatoid arthritis previously untreated with methotrexate. Arthritis Care Res (Hoboken) 2011;63(5):711-20. 
10. Smolen JS, Landewé R, Breedveld FC, Buch M, Burmester G, Dougados M, et al. EULAR recommendations for the management of rheumatoid arthritis with synthetic and biological disease-modifying antirheumatic drugs: 2013 update. Ann Rheum Dis. 2014;73(3):492-509.

11. Mariette X, Rouanet S, Sibilia J, Combe B, Le Loët X, Tebib J, et al. Evaluation of low-dose rituximab for the retreatment of patients with active rheumatoid arthritis: a non-inferiority randomised controlled trial. Ann Rheum Dis. 2014;73(8):1508-14.

12. Arnett FC, Edworthy SM, Bloch DA, McShane DJ, Fries JF, Cooper NS, et al. The American Rheumatism Association 1987 revised criteria for the classification of rheumatoid arthritis. Arthritis Rheum 1988;31:315-24.

13. Bruce B, Fries JF. The Stanford Health Assessment Questionnaire: a review of its history, issues, progress, and documentation. J Rheumatol. 2003;30(1):167-78.

14. Hays RD, Stewart AL. Measuring function and well being. The medical outcomes study approach sleep measures. Durham North Carolina, USA: Duke University Press 1992:235-59.

15. Ware J Jr, Kosinski M, Keller SD. A 12-item Short-Form Health Survey: construction of scales and preliminary test of reliability and validity. Med Care 1996; 34: 220-233.

16. Fransen J, van Riel PL: The disease activity score and the EULAR response criteria. Clin Exp Rheumatol 2005, 23(5 Suppl 39):S93-S99.

17. Zou GY. Quantifying responsiveness of quality of life measures without an external criterion. Qual Life Res. 2005; 14(6):1545-52.

18. Husted JA, Cook RJ, Farewell VT, Gladman DD. Methods for assessing responsiveness: a critical review and recommendations. J Clin Epidemiol. 2000;53(5):459-68.

19. Keystone E, Burmester GR, Furie R, Loveless JE, Emery P, Kremer J, et al. Improvement in patient-reported outcomes in a rituximab trial in patients with severe rheumatoid arthritis refractory to anti-tumor necrosis factor therapy. Arthritis Rheum. 2008;59(6):785-93.

20. Verstappen SM, Symmons DP. What is the outcome of RA in 2011 and can we predict it? Best Pract Res Clin Rheumatol. 2011;25(4):485-96. 
21. Chauffier K1, Salliot C, Berenbaum F, Sellam J. Effect of biotherapies on fatigue in rheumatoid arthritis: a systematic review of the literature and meta-analysis. Rheumatology (Oxford). 2012;51(1):60-8. 